\title{
Investigation of peptide size, residue position, neighbor amino acid and side chain effect on macrocyclization of $b_{n}(n=5-7)$ ions
}

\author{
Cagdas Tasoglu, Guvenc Gorgulu, Talat Yalcin* \\ Department of Chemistry, Faculty of Science, Izmir Institute of Technology, Izmir 35430, Turkey
}

\section{A R T I C L E I N F O}

\section{Article history:}

Received 30 October 2011

Received in revised form 27 January 2012

Accepted 1 February 2012

Available online 9 February 2012

\section{Keywords:}

Macrocyclization

Preferential opening

Peptide size

Amino acid side chain

Amino acid position

Neighbor amino acid

\begin{abstract}
A B S T R A C T
A systematic study was carried out to examine the effects of the side chain, peptide size, residue position, and neighboring amino acid on the macrocyclization of $b$ ions. The work utilized isomeric model peptides YAGFLV- $\mathrm{NH}_{2}$, AGFLVY-NH $\mathrm{N}_{2}$, GFLVYA- $\mathrm{NH}_{2}$, FLVYAG- $\mathrm{NH}_{2}$, LVYAGF- $\mathrm{NH}_{2}$, VYAGFL- $\mathrm{NH}_{2}$, which all have the same amino acid sequence in cyclic form. The $b_{6}$ ions derived from all these isomeric peptides form the same macrocyclic structure due to the generation of the same amino acid sequence order upon cyclization. Hence, the MS/MS spectra and breakdown graphs of $b_{6}$ ions derived from these peptides are similar to each other. However, the relative intensities of the non-direct sequence ions in both the MS/MS spectra and breakdown graphs of the $b_{6}$ ions derived from FAYVGL- $\mathrm{NH}_{2}$, GVYALF- $\mathrm{NH}_{2}$ and VFYLAG- $\mathrm{NH}_{2}$ show a different distribution from each other and the first series, even though they are all isomeric peptides. This could be due to the different amino acid sequence order in the cyclic forms of these peptides. It is clearly shown that the neighboring amino acid influences the selective opening of the macrocyclic form. Additionally, XYAGFLV- $\mathrm{NH}_{2}$ and YAGXFLV- $\mathrm{NH}_{2}$ (where $\mathrm{X}=\mathrm{C}, \mathrm{D}, \mathrm{E}, \mathrm{H}, \mathrm{K}, \mathrm{M}, \mathrm{N}, \mathrm{P}, \mathrm{Q}, \mathrm{S}, \mathrm{T}$, and $\mathrm{W}$ are amino acid residues) were also studied in order to examine the influence of the peptide size, amino acid side chain, and position on the ring formation and cleavage of macrocyclic $b_{5}, b_{6}$ and $b_{7}$ ions. The results have clearly shown that $b_{6}$ and $b_{7}$ ions have a higher tendency of macrocyclization compared to $b_{5}$ ions with the exception of QYAGFLV- $\mathrm{NH}_{2}$. Additionally, it was observed that selective ring opening is also dependent on the size of the $b$ ions and the position of the amino acid residue. From our study of the macrocyclic $b_{6}$ ions of our model peptides, the $\mathrm{Q}, \mathrm{W}, \mathrm{K}$, and $\mathrm{M}$ residues were found to be more favorable eliminations when compared to C, D, E, H, N, P, S, and T. Based on the results, no preferential cleavage order can be specified depending on the nature of amino acid side chain.
\end{abstract}

(C) 2012 Elsevier B.V. All rights reserved.

\section{Introduction}

Following the invention of soft ionization methods such as electrospray ionization (ESI) [1,2] and matrix-assisted laser desorption/ionization (MALDI) [3,4], tandem mass spectrometry (MS/MS) in combination with collision-induced dissociation (CID) [5] has been utilized as a routine means of protein sequencing in proteomics [6-8]. In low-energy CID, protonated peptides are cleaved at the amide bonds to generate a series of $\mathrm{N}$-terminal $b$ ions and/or C-terminal $y$ ions $[9,10]$ and later on, these ions can be used to sequence peptides produced from the enzymatic cleavage of unknown proteins. The structure of the $y$ ions has been proven to be protonated truncated peptides [11-13] while a number of different structural forms have been established for the $b$ fragment ions. Early studies $[9,10]$ have suggested that the structure of the $b$ ions was an acylium ion. Yalcin et al.

\footnotetext{
* Corresponding author. Tel.: +90 232 7507625; fax: +90 7507509.

E-mail address: talatyalcin@iyte.edu.tr (T. Yalcin).
}

[14] however, originally proposed that cyclization takes place via nucleophilic attack of adjacent carbonyl oxygen on the N-terminus to form a five-membered oxazolone ring structure of $b$ ions.

Several studies have also supported this mechanism using infrared multiple photon dissociation (IRMPD) [15-19] and isotopic labeling techniques [20]. However, the existence of a strong nucleophile in the peptide backbone may cause side chain-specific cyclization reactions [21-28]. Diketopiperazine structures have also been postulated as structure for $b_{2}$ ions [12,13]. Recently, Wysocki et al. [29] reported that the $b_{2}$ ion obtained from HA has a combination of oxazolone and diketopiperazine structures. It could be said that the existence of two structures for $b_{2}{ }^{+}$fragments may not be general and may depend on the amino acid sequence.

Vachet et al. [30], and Yagüe et al. [31] reported that the internal amino acid residue eliminations are due to the intermolecular rearrangement and that this can make the interpretation of peptide MS/MS spectra more difficult. Since 2006, a large number of publications [32-41] have been published about the macrocyclization reactions of $b_{n}$ ions $(n \geq 5)$. They have shown that cyclization may occur through the attack of the free $\mathrm{N}$-terminal amino group 
on the charged C-terminal oxazolone ring and that the subsequent opening of this macrocyclic ring at various amide bond positions could produce "non-direct" sequence ions.

Recently, the effect of peptide size [39] on the macrocyclization of $b$ ions and the effect of amino acid nature [42] on the potential ring opening of this cyclic model at various amide bonds have been studied by Stipdonk et al. However, they have only considered a single isomeric series of the YAGFLVG model to monitor the macrocyclization of $b$ ions, and focused only on the $b_{5}$ ions produced from YAXFLG (where X = G, K, E, D, N, Q) to obtain information about the side chain effect. In addition, Polfer et al. published a detailed study about $b_{2}-b_{8}$ ions to predict the influence of the peptide size on cyclization [43]. It was observed that the smaller $b$ fragments $\left(b_{2}\right.$, $b_{3}$ ) form an oxazolone structure, in contrast midsized ones $\left(b_{4}-b_{7}\right)$ generate a combination of oxazolone and macrocylic structures.
In this work, we have carried out a more comprehensive systematic study to examine the effects of peptide size, residue position, neighboring amino acid and side chain on the macrocyclization and the potential ring opening of macrocyclic $b_{n}(n=5-7)$ ions. The study utilized two sets of model peptides. The first set was isomeric peptide series of YAGFLV-NH $\mathrm{N}_{2}$ to examine the neighboring amino acid effect on the ring cleavage of macrocyclic $b$ ions. The second set was XYAGFLV-NH $\mathrm{N}_{2}$ and YAGXFLV-NH where $\mathrm{X}$ denotes $\mathrm{C}, \mathrm{D}, \mathrm{E}, \mathrm{H}, \mathrm{K}, \mathrm{M}, \mathrm{N}, \mathrm{P}, \mathrm{Q}, \mathrm{S}, \mathrm{T}$, and $\mathrm{W}$ amino acid residues. The position of the $\mathrm{X}$ amino acid residue was varied to examine the influence of the amino acid position and side chain on the ring formation and cleavage $\left(b_{5}-\mathrm{X}, b_{6}-\mathrm{X}\right.$ and $b_{7}-\mathrm{X}$ ) of macrocyclic $b$ ions. Moreover, the collision energy dependence of the preferential cleavage of macrocyclic $b$ ions was also studied.
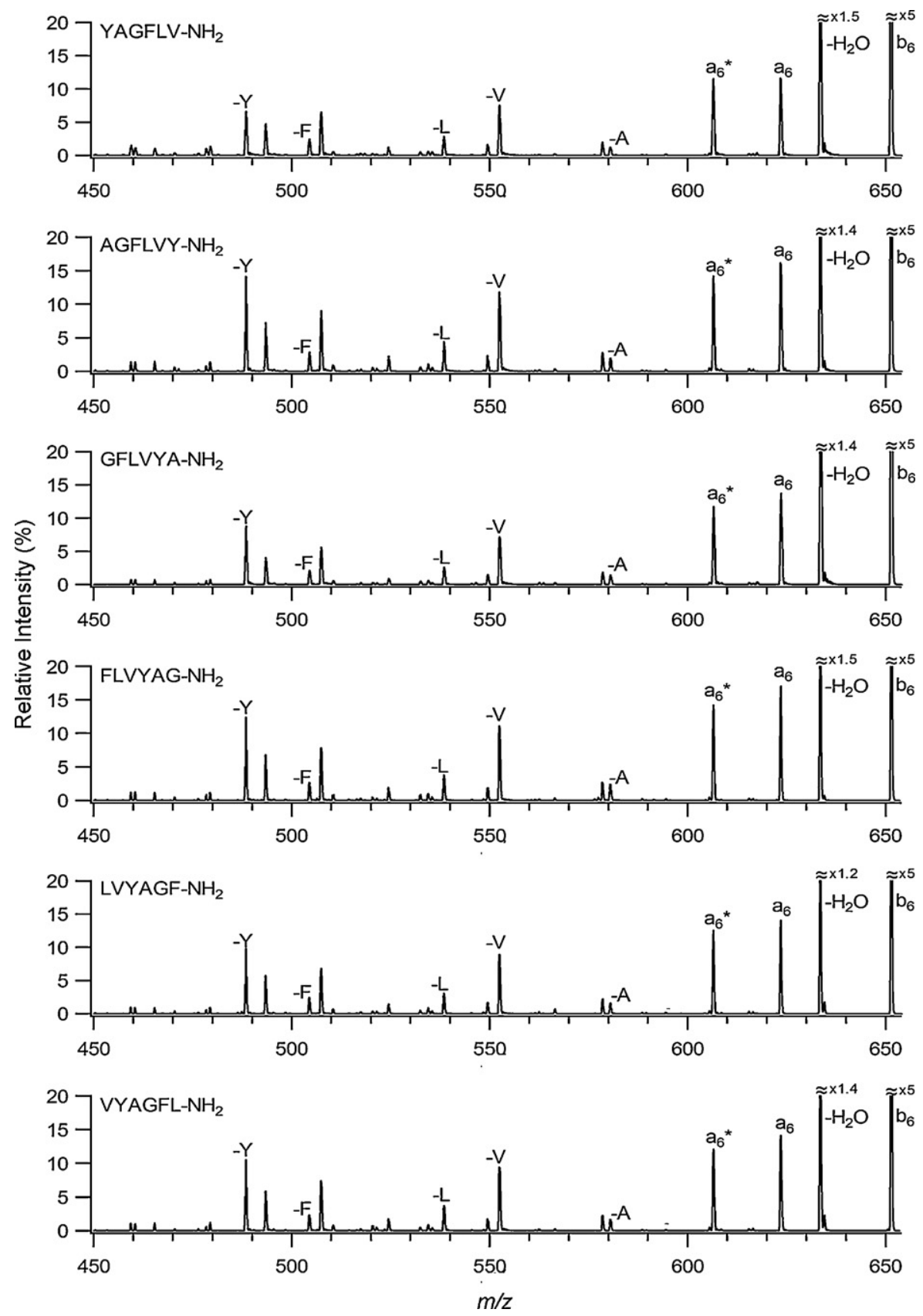

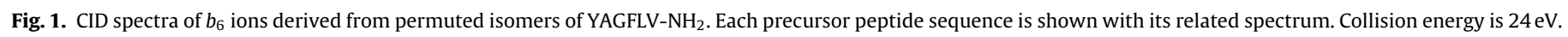



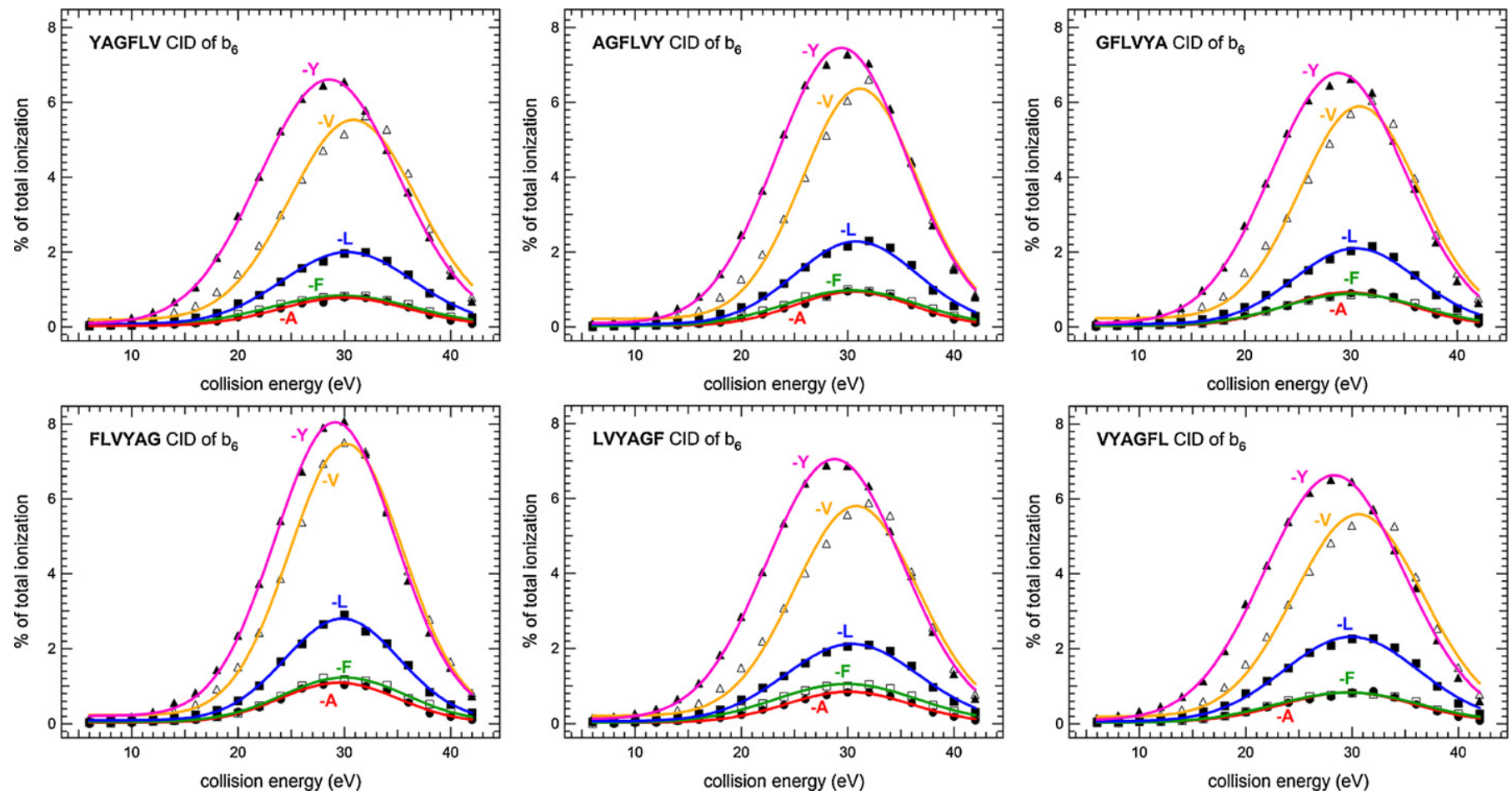

Fig. 2. Breakdown graphs for $b_{6}$ ions derived from permuted isomers of YAGFLV-NH 2 . Nondirect sequence ions have shown only.

\section{Experimental}

\subsection{Materials}

All synthetic C-terminally amidated model peptides were obtained from GL Biochem (Shangai, China) and used as received with no further purification. HPLC grade methanol and formic acid were supplied by Merck (Darmstadt, Germany). The water used was ultrapure grade (Arium 611 UV, Sartorius AG, Goettingen, Germany). Stock solutions of peptides were prepared by dissolving solid material in a 1:1 (v/v) mixture of methanol and water to a concentration of $10^{-2} \mathrm{M}$. Peptide samples at micromolar concentration level were dissolved in $1: 1 \mathrm{CH}_{3} \mathrm{OH}: \mathrm{H}_{2} \mathrm{O}$ containing $1 \%$ formic acid.

\subsection{Mass spectrometry}

All low-energy CID experiments were conducted on a hybrid triple quadrupole/linear ion trap 4000 QTRAP instrument (Applied Biosystems/MDS Sciex, Ontario, Canada) which is equipped with an electrospray ionization source. The peptide solutions were infused into the electrospray source at a $5 \mu \mathrm{L} / \mathrm{min}$ flow rate using a syringe pump from Harvard Apparatus (model 11 plus, Natick, MA, USA).

Nitrogen was used as nebulizer, curtain, and collision gas. The Q1 scan was applied first to adjust the declustering potential for the generation of the most intense ion signal with the best Gaussian distribution peak shape, which was then followed by enhanced product ion (EPI) scan for MS/MS experiments of $b$ ion fragments in the collision cell. The EPI scan studies were operated using the following 4000 QTRAP instrumental parameters: curtain gas (CUR), 10.00 arbitrary units (arb); ion spray voltage (IS), 5500.00; temperature (TEM), $0.00^{\circ} \mathrm{C}$; ion source gas 1 (GS1), 19.00; ion source gas 2 (GS2), 0.00; interface heater (ihe), On; collision gas (CAD), 6.00 arb; collision energy spread (CES), 0.00; collision energy (CE), $6.0-42.0 \mathrm{eV}$ (with increments of $2.0 \mathrm{eV}$ ), quadrupole 1 ion energy (IE1), 0.800; Q1 resolution, unit; detector channel electron multiplier (CEM), 2200.0; scan rate, $1000 \mathrm{Da} / \mathrm{s}$; linear ion trap (LIT) fill time, $20 \mathrm{~ms}$. All MS/MS data were collected as a sum of the 50 multichannel analysis (MCA) scans in centroid mode. Analyst 1.5 software was used for the instrument control, data acquisition and processing.

\section{Results and discussion}

\subsection{Influence of neighbor amino acid on preferential opening of macrocyclic $b$ ion}

The MS/MS spectra of $b_{6}(651 \mathrm{~m} / z)$ ions derived from YAGFLV$\mathrm{NH}_{2}$, AGFLVY-NH $\mathrm{N}_{2}$, GFLVYA-NH $\mathrm{N}_{2}$, FLVYAG-NH $\mathrm{N}_{2}$, LVYAGF- $\mathrm{NH}_{2}$, and VYAGFL-NH $\mathrm{N}_{2}$ are presented in Fig. 1. They produce both direct and nondirect sequence ions in agreement with the literature studies $[32,34,35,38,39]$, and display nearly an identical fragmentation pattern. This is because the $b_{6}$ ions derived from the isomeric peptides form the same macrocyclic structure due to the generation of the same amino acid sequence order upon cyclization. The main product ions include $\mathrm{H}_{2} \mathrm{O}$ elimination $(633 \mathrm{~m} / \mathrm{z}), a_{6}$ ion $(623 \mathrm{~m} / \mathrm{z})$, and $a_{6}{ }^{*}$ ion $(606 \mathrm{~m} / z)$. Additionally, all the spectra show significant nondirect sequence ions as the eliminations of Y $(488 \mathrm{~m} / \mathrm{z}), \mathrm{A}(580$ $\mathrm{m} / \mathrm{z}), \mathrm{F}(504 \mathrm{~m} / \mathrm{z}), \mathrm{L}(538 \mathrm{~m} / \mathrm{z})$, and $\mathrm{V}(552 \mathrm{~m} / \mathrm{z})$. It was noticed that in previous studies the MS/MS experiments concerning the macrocyclization of $b$ ions were performed at a single collision energy value. Therefore, the collision energy dependence of the preferential cleavage of macrocyclic $b$ ions was also investigated. Fig. 2 shows the breakdown graph of these isomeric peptides considering nondirect sequence ions only. However, it should be noted that some of the non-direct sequence amino acid eliminations might overlap with the direct sequence ions (e.g., $b_{6}-\mathrm{V}$ from YAGFLV might overlap with the $b_{5}$ ion). As one can easily see, they all follow nearly the same dissociation pattern regardless of the peptide sequence. Interestingly, the elimination tendency of each internal amino acid residue from the $b_{6}$ ion is same for all model peptides. A decreasing trend was shown in the order of $\mathrm{Y}>\mathrm{V}>\mathrm{L}>\mathrm{F} \sim \mathrm{A}$. The internal elimination of tyrosine was observed to be the most dominant event ( $\sim 7 \%$ of total ion current at maxima) 

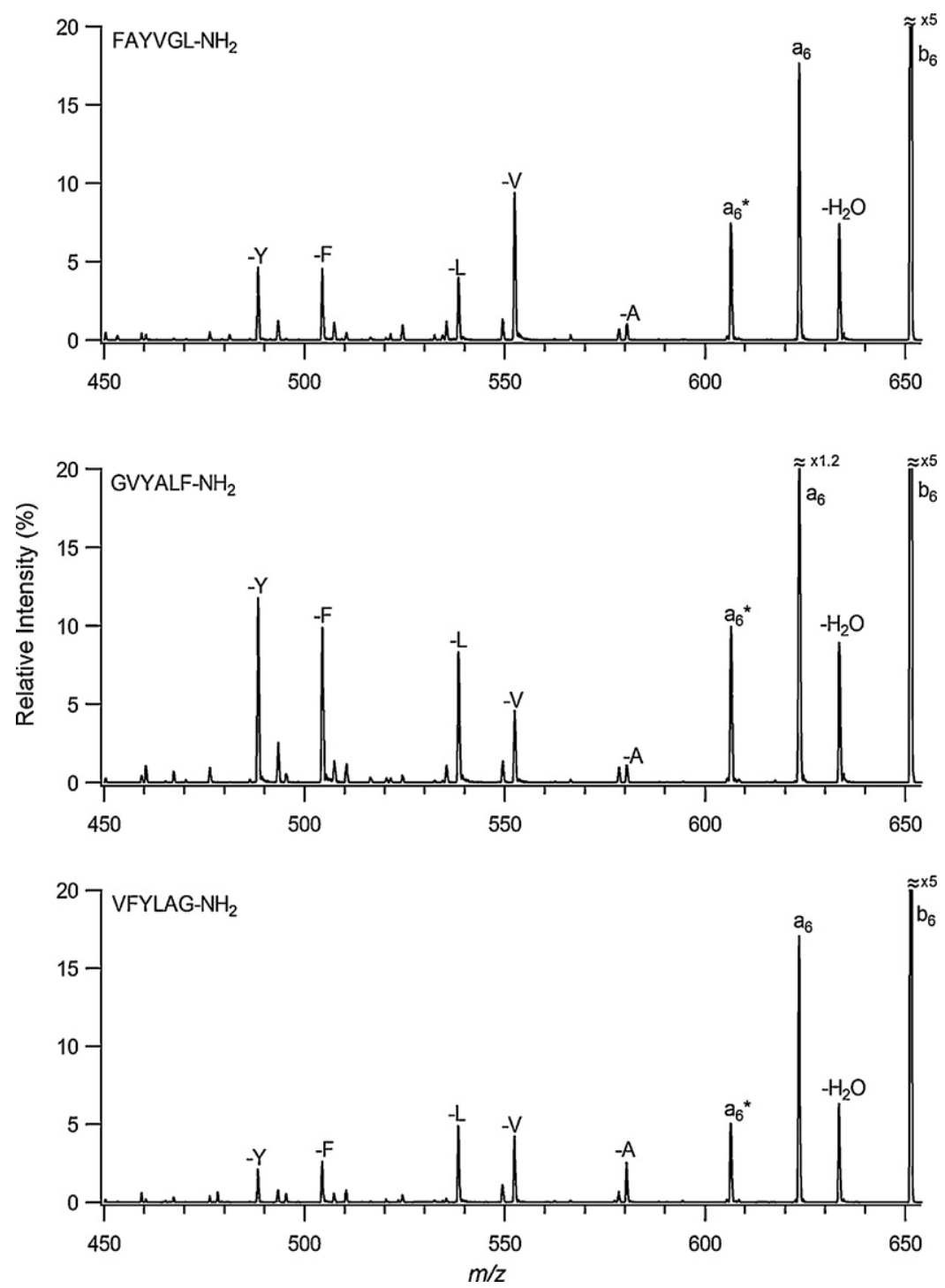

Fig. 3. CID spectra of $b_{6}$ ions of derived from FAYVGL-NH 2, GVYALF-NH $\mathrm{N}_{2}$, and VFYLAG- $\mathrm{NH}_{2}$. Collision energy is $24 \mathrm{eV}$.

compared to the other eliminations. The results suggested that the ring-opening from the $\mathrm{A}-\mathrm{Y}$ bond forming $\mathrm{AGFLVY}$ oxa linear hexapeptide isomer is energetically the most favored pathway and is in excellent agreement with the work previously published by Harrison et al. [34], which through scanning the potential energy surfaces, found that the energetically most favored ring-opening transition structure is $A_{G F L Y}$ oxa. However, the relative intensities of nondirect sequence ions in both the MS/MS spectra (as shown in Fig. 3) and breakdown graphs (as shown in Fig. 4) of $b_{6}$ ions derived from FAYVGL-NH ${ }_{2}$, GVYALF- $\mathrm{NH}_{2}$ and VFYLAG- $\mathrm{NH}_{2}$ show different distributions with each other. As can be seen in Fig. 3, the distribution of the non-sequence ion intensities are also different from the other series shown in Fig. 1 even though they are all isomeric peptides. This could be due to the formation of a different
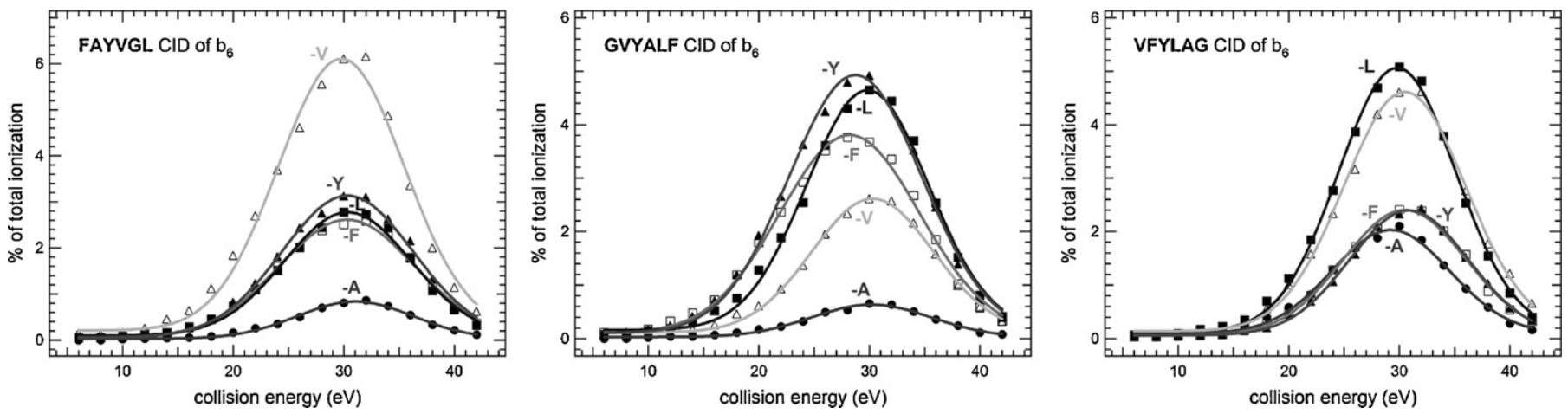

Fig. 4. Breakdown graphs for $b_{6}$ ions derived from FAYVGL- $\mathrm{NH}_{2}$, GVYALF- $\mathrm{NH}_{2}$, and VFYLAG-NH . Nondirect sequence ions have shown only. 


\section{X: ACIDIC}
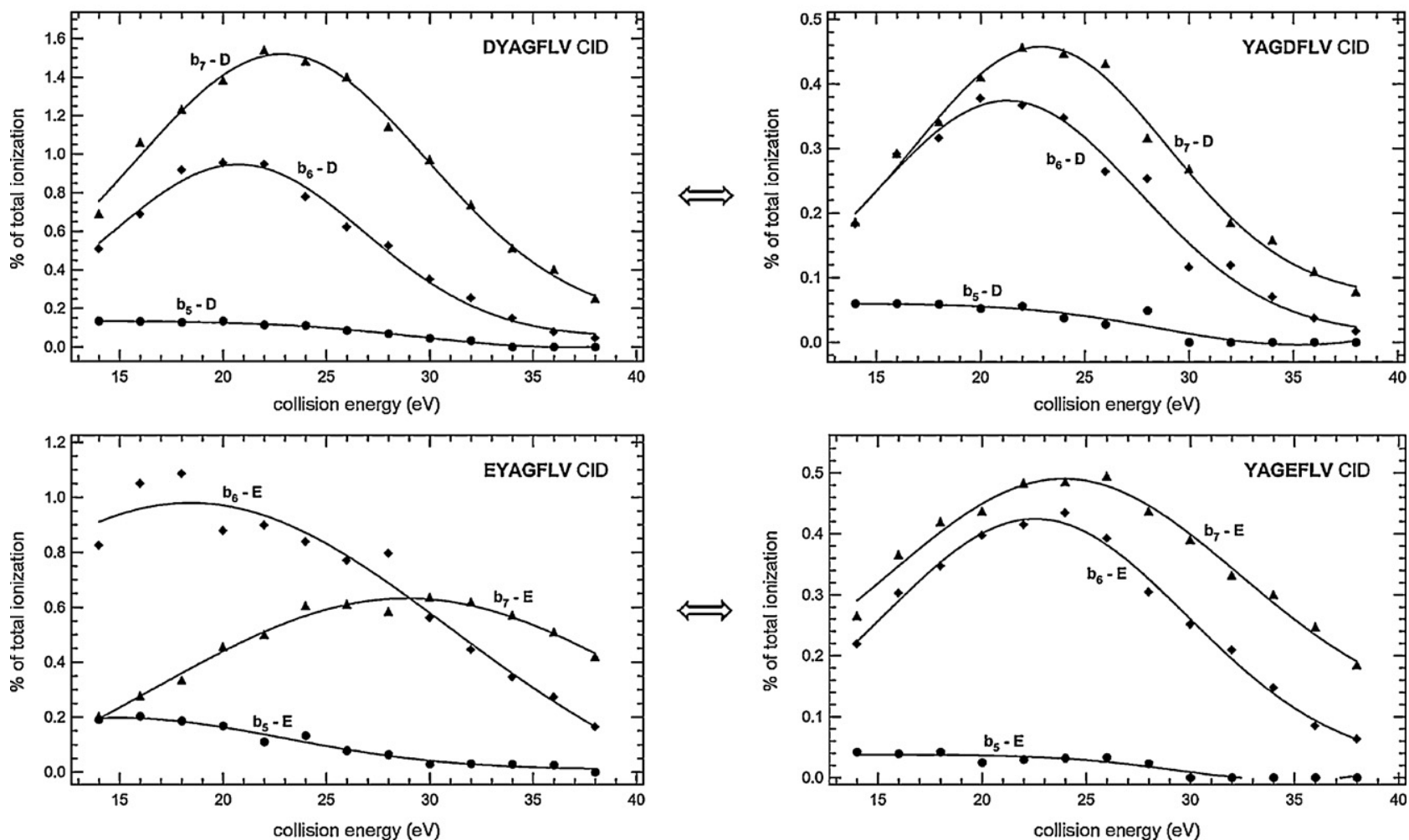

Fig. 5. Breakdown graphs for elimination of $\mathrm{X}$ from $\mathrm{XYAGFLV-NH_{2 }}$ and $\mathrm{YAGXFLV-NH_{2 }}$, where $\mathrm{X}$ is aspartic acid, D, and glutamic acid, E.

\section{X: BASIC}
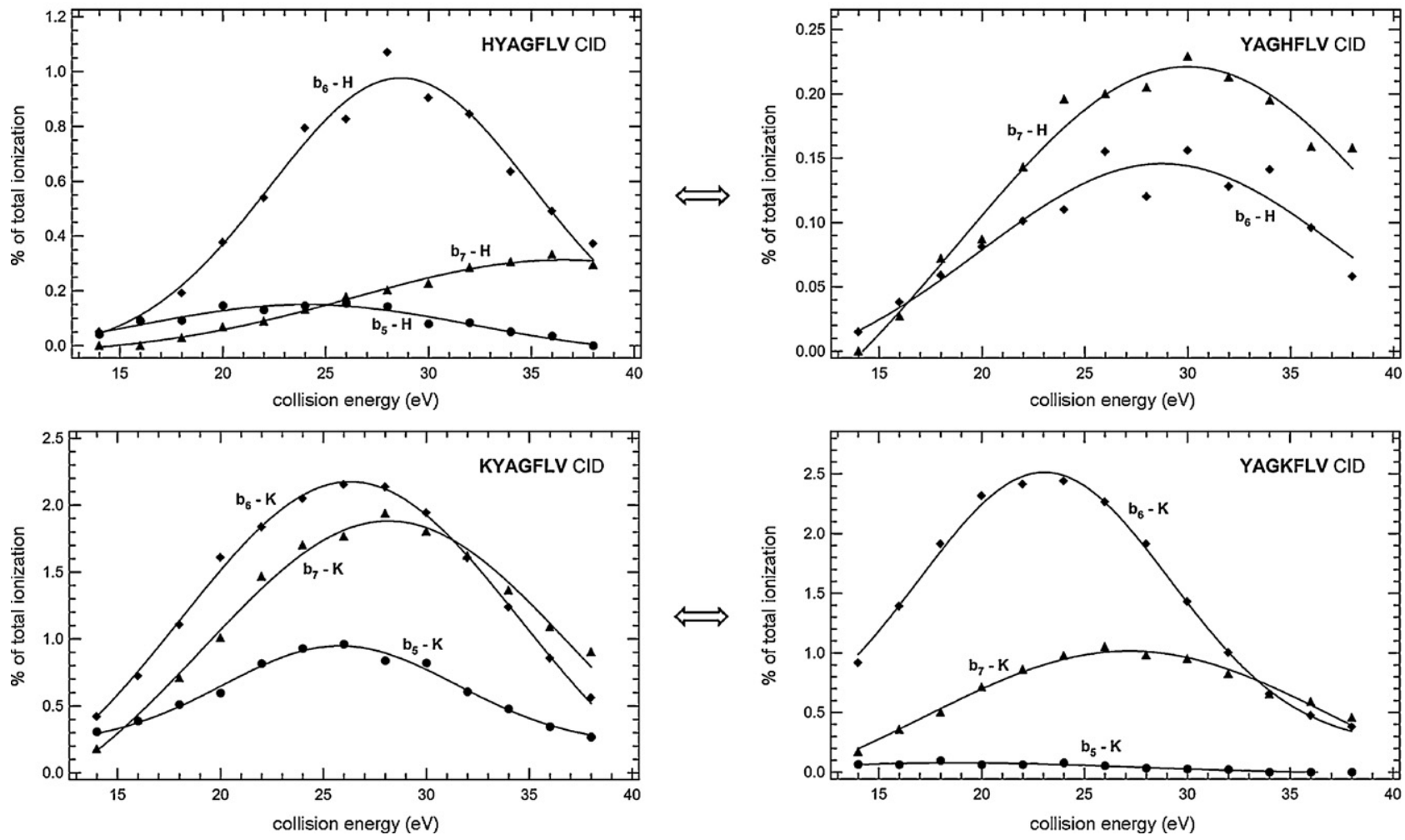

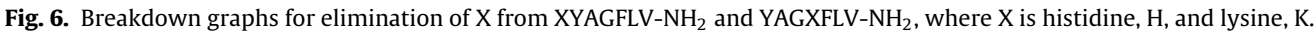




\section{$\mathrm{X}$ : NONPOLAR}
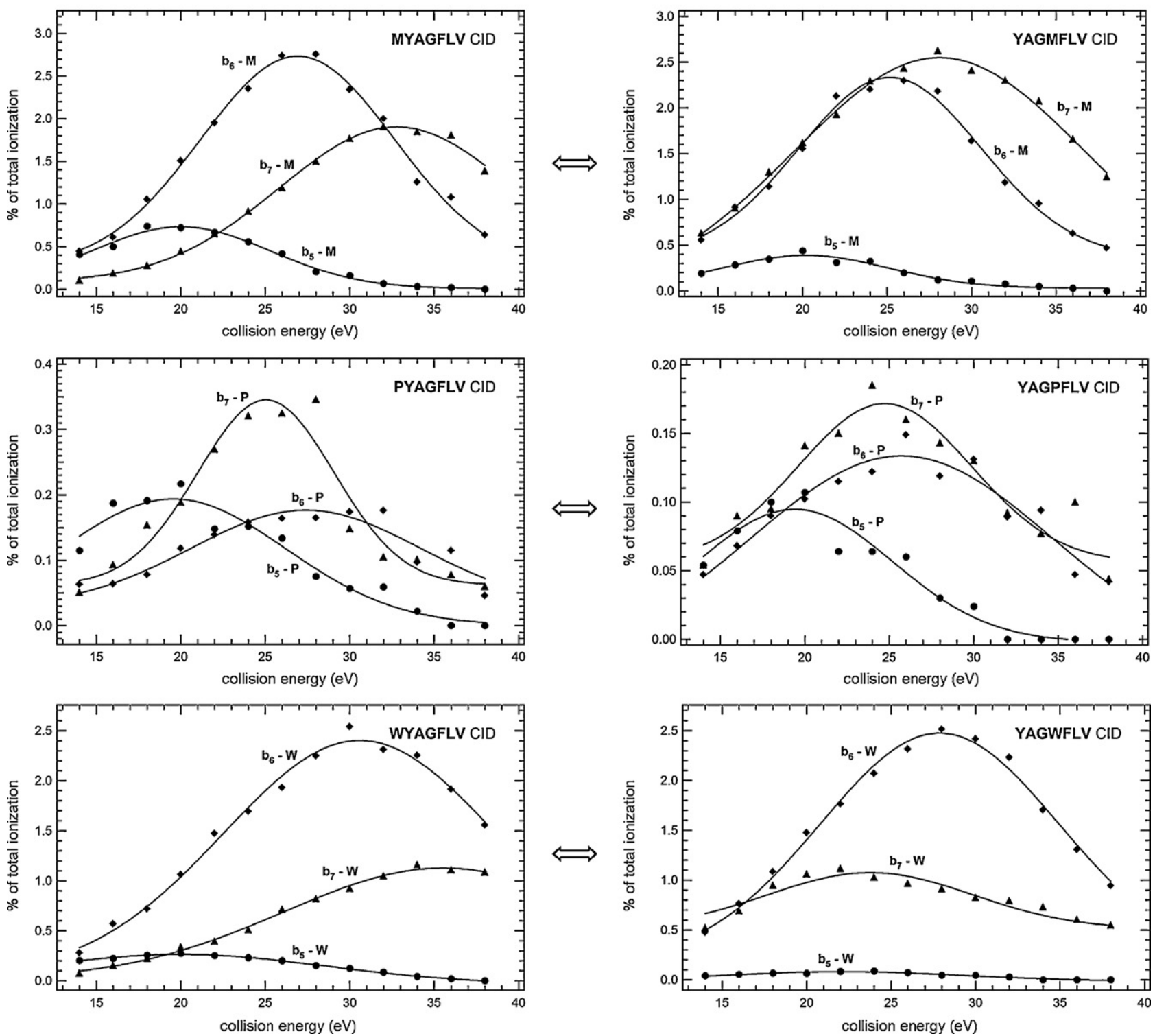

Fig. 7. Breakdown graphs for elimination of $\mathrm{X}$ from XYAGFLV- $\mathrm{NH}_{2}$ and $Y A G X F L V-\mathrm{NH}_{2}$, where $\mathrm{X}$ is methionine, M, proline, $\mathrm{P}$, and tryptophan, $\mathrm{W}$.

amino acid sequence order in the cyclic forms of these peptides. It was clearly shown that the neighboring amino acid has influenced the selective opening of the macrocyclic $b_{6}$ ion. The breakdown graphs of these peptides (as shown in Fig. 4) have totally different distributions when compared to each other and the results which are shown in Fig. 2. Based on these findings, the single residue elimination orders are observed as $\mathrm{V}>\mathrm{Y}>\mathrm{L} \sim \mathrm{F}>\mathrm{A}, \mathrm{Y}>\mathrm{L}>\mathrm{F}>\mathrm{V}>\mathrm{A}$, and $\mathrm{L}>\mathrm{V}>\mathrm{F} \sim \mathrm{Y}>\mathrm{A}$ for FAYVGL- $\mathrm{NH}_{2}$, GVYALF- $\mathrm{NH}_{2}$, and VFYLAG$\mathrm{NH}_{2}$, respectively. Nevertheless, alanine has the lowest tendency to be eliminated from the macrocycle regardless of the sequence.

\subsection{Influence of $b$ ion size, amino acid side chain, and position on preferential opening of macrocyclic $b$ ion}

Recently, Stipdonk et al. have demonstrated that the preferential opening of the macrocyclic $b$ ion structure is directly affected by the peptide size [39] and the nature of the amino acid side chain [41]. They have performed a CID of the $b_{5}$ ion derived from YAXFLG model sequence (where $\mathrm{X}$ is $\mathrm{G}, \mathrm{K}, \mathrm{E}, \mathrm{D}, \mathrm{N}, \mathrm{Q}$ ), and compared the peak intensities related to the loss of $\mathrm{X}$ from the $b_{5}$ ion.
Using this approach, the $b_{5}-\mathrm{X}$ trend is found to follow the order of $\mathrm{Q}>\mathrm{K}>\mathrm{D}>\mathrm{N} \sim \mathrm{E}$ (no G elimination observed). However, they have only considered a single $b$ ion size $\left(b_{5}\right)$, a single residue position, and a limited number of amino acid residues. In this study, on the other hand, we have extended this approach by examining the effect of the amino acid side chain using a variety of residues, changing the residue position, and investigating the $b$ ion size $\left(b_{5}-b_{7}\right)$ on the ring formation and cleavage ( $b_{5}-\mathrm{X}, b_{6}-\mathrm{X}$, and $\left.b_{7}-\mathrm{X}\right)$ of macrocyclic $b$ ions. For this purpose, the peptide series have been designed as XYAGFLV- $\mathrm{NH}_{2}$ and YAGXFLV- $\mathrm{NH}_{2}$ where $\mathrm{X}$ denotes $\mathrm{C}, \mathrm{D}, \mathrm{E}, \mathrm{H}$, $\mathrm{K}, \mathrm{M}, \mathrm{N}, \mathrm{P}, \mathrm{Q}, \mathrm{S}, \mathrm{T}$, and $\mathrm{W}$ amino acid residues. The model peptides are divided into four main groups based on the side-chain nature of $\mathrm{X}$ residue such as acidic $(\mathrm{D}, \mathrm{E})$, basic $(\mathrm{H}, \mathrm{K})$, nonpolar $(\mathrm{M}, \mathrm{P}, \mathrm{W})$, and polar $(\mathrm{C}, \mathrm{N}, \mathrm{Q}, \mathrm{S}, \mathrm{T})$ groups. The collision energy dependence of the preferential cleavage of acidic, basic, nonpolar and polar peptide series are shown in Figs. 5-8, respectively. As is apparent in the graphs, the N-terminal position and the central position of all the residues mentioned above were considered. The results clearly show that $b_{6}$ and $b_{7}$ ions have a higher tendency toward macrocyclization compared to the $b_{5}$ ions with the 


\section{X: POLAR}
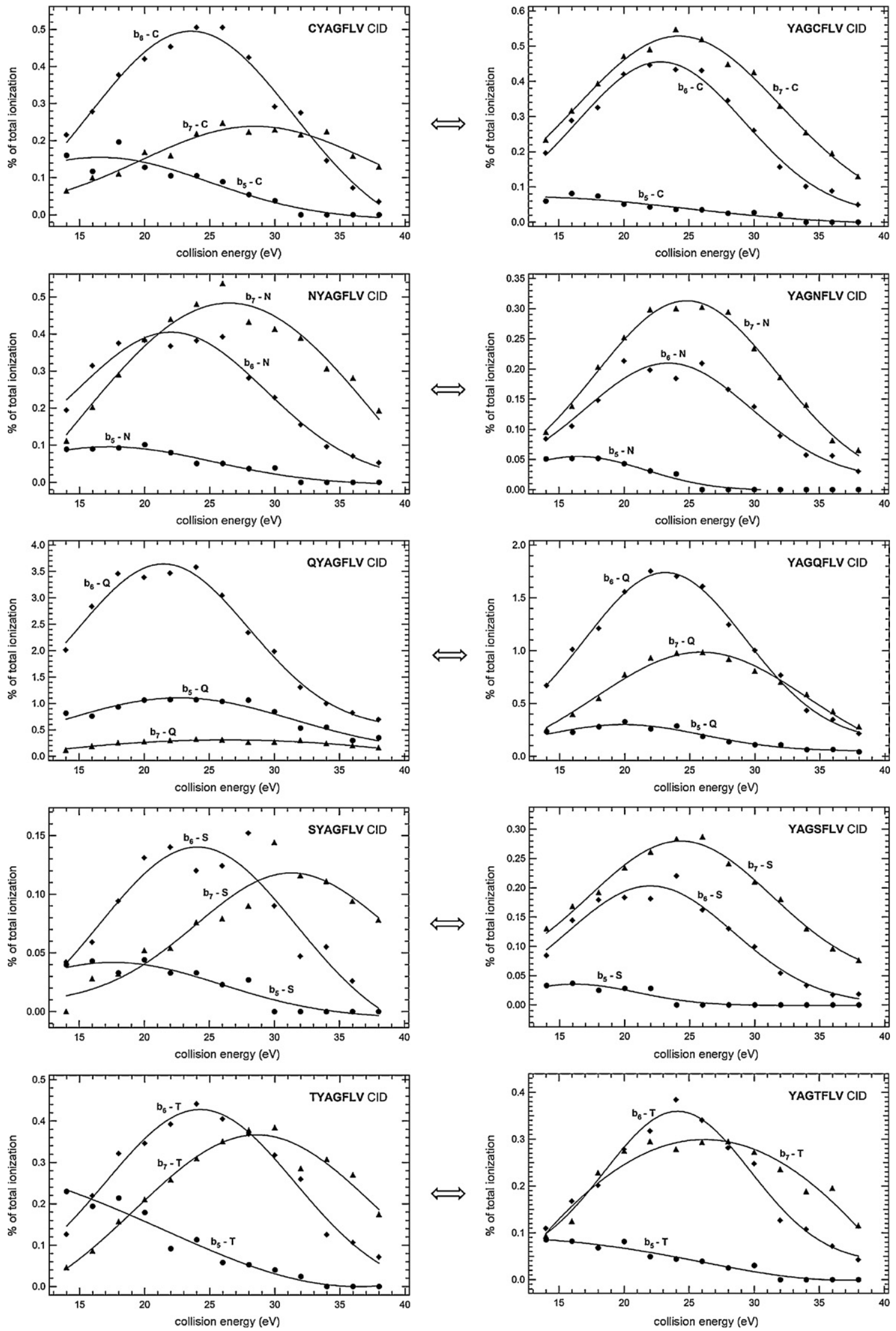

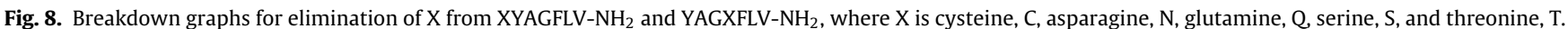


exception of QYAGFLV- $\mathrm{NH}_{2}$ which shows a higher tendency toward macrocyclization of the $b_{5}$ ion compared to that of the $b_{7}$ ion where $b_{5}-\mathrm{Q}>b_{7}-\mathrm{Q}$. There is no such an observation for asparagine although its side chain is similar to glutamine. This interesting behavior of glutamine is presently under investigation in our laboratory. In addition, it has been observed that the selective ring opening is also dependent on the size of the $b$ ions and the position of the amino acid residue. It was shown that the elimination of N-terminally positioned aspartic acid or glutamic acid from $b_{6}$ or $b_{7}$ is favored compared to the central position case. Both, $b_{6}-\mathrm{X}$ and $b_{7}-\mathrm{X}$ (where $\mathrm{X}=\mathrm{D}$ or $\mathrm{E}$ ) showed similar distributions except for EYAGFLV-NH $\mathrm{N}_{2}$ (shown in Fig. 5).

The $\mathrm{N}$-terminal and central position of the lysine residue showed a similar distribution when comparing to $b_{6}-\mathrm{K}$ profiles. In contrast, the $b_{7}-\mathrm{K}$ elimination from the $\mathrm{N}$-terminal and the central position did not show a similar distribution (shown in Fig. 6). The preferential cleavage of $b_{5}-\mathrm{K}$ showed different distribution when $\mathrm{N}$-terminal position is compared to the central position. In Fig. 6 , it is shown that the $b_{6}-\mathrm{H}$ cleavages from the N-terminal and central position are similar. By contrast, the $b_{7}-\mathrm{H}$ cleavage from the $\mathrm{N}$-terminal and central position showed a different distribution. In addition, the $b_{5}-\mathrm{H}$ cleavage from $\mathrm{N}$-terminal position is low abundant and is in agreement with the report by Harrison et al. [44]. However, no acceptable signal was observed for central position.

Among the nonpolar residues, preferential cleavage of the proline residue from $b_{5}, b_{6}$, and $b_{7}$ showed similar distributions no matter where the position of the proline residue is (shown in Fig. 7). However, N-terminal and central position of the methionine showed a similar distribution when considering $b_{6}$ ions; although, $b_{7}$ showed a different distribution. The major difference observed for tryptophan is the preferential cleavage from $b_{7}-\mathrm{W}$ for the Nterminal and central positions.

Among the polar residues, they all showed a similar distribution for $b_{5}, b_{6}$ and $b_{7}$ when compared the N-terminal to central position (exception of QYAGFLV- $\mathrm{NH}_{2}$ ). It should be also mentioned that some internal amino acid elimination from $b_{6}$ or $b_{7}$ might show slight changes in terms of intensity distribution in breakdown graph such as, cysteine, serine (shown in Fig. 8).

Finally, among the all amino acid residues, $\mathrm{Q}, \mathrm{W}, \mathrm{K}$, and $\mathrm{M}$ were found to be more favored eliminations from macrocyclic $b_{6}$ ion. Different from Stipdonk et al. [39,41], our results have shown that no preferential cleavage order can be specified depending on the nature of amino acid side chain.

\section{Conclusion}

This systematic study of isomeric peptides clearly indicates that $b_{6}$ and $b_{7}$ ions have a higher tendency toward macrocyclization when compared to $b_{5}$ ions with the exception of QYAGFLV-NH showing a higher tendency toward macrocyclization of the $b_{5}$ ion compared to that of the $b_{7}$ ion where $b_{5}-\mathrm{Q}>b_{7}-\mathrm{Q}$. We have also observed that the distribution of the nondirect sequence ion intensities of the first series (YAGFLV- $\mathrm{NH}_{2}$, AGFLVY- $\mathrm{NH}_{2}$, GFLVYA- $\mathrm{NH}_{2}$, FLVYAG- $\mathrm{NH}_{2}$, LVYAGF- $\mathrm{NH}_{2}$, and VYAGFL- $\mathrm{NH}_{2}$ ) are different from that of second series (FAYVGL-NH $\mathrm{N}_{2}$, GVYALF- $\mathrm{NH}_{2}$, and VFYLAG$\mathrm{NH}_{2}$ ) although they are all isomeric peptides. This could be likely due to the change of the amino acid sequence order in the cyclic forms of these peptides, and it has clearly been shown that the neighboring amino acid influences the selective opening of the macrocyclic $b_{6}$ ion. The selective ring opening is also dependent on the size of the $b$ ions and the position of the amino acid residue. It has also been found that no preferential cleavage order can be specified depending on the nature of amino acid side chain. Finally, $\mathrm{Q}, \mathrm{W}, \mathrm{K}$, and $\mathrm{M}$ were found to be more favored eliminations from the macrocyclic $b_{6}$ ion compared to the $b_{5}$ ion.

\section{Acknowledgments}

T. Yalcin gratefully thanks Prof. A.G. Harrison for his guidance and invaluable discussion about the fragmentation mechanism of gas-phase ions' chemistry since 1994 . We are appreciative of the financial support from the Scientific and Technological Research Council of Turkey, TUBITAK (Project No.: 109T430). The State Planning Organization, DPT, (Project No.: 2008K120730) is also gratefully acknowledged for its financial support of the Mass Spectrometry Facility. Finally, C.T. and G.G. acknowledge TUBITAK for financial support of their graduate and postgraduate research.

\section{References}

[1] M. Yamashita, J.B. Fenn, Electrospray ion source. Another variation on the freejet theme, J. Am. Chem. Soc. 88 (1984) 4451-4459.

[2] J.B. Fenn, M. Mann, C.K. Meng, S.F. Wong, C.M. Whitehouse, Electrospray ionization for mass spectrometry of large biomolecules, Science 246 (1989) 64-71.

[3] M. Karas, F. Hillenkamp, Laser desorption ionization of proteins with molecular masses exceeding 10,000 Daltons, Anal. Chem. 60 (1988) 2299-2301.

[4] F. Hillenkamp, M. Karas, R.C. Beavis, B.T. Chait, Matrix-assisted laser desorption ionization mass-spectrometry of biopolymers, Anal. Chem. 63 (1991) A1193-A1202.

[5] S.A. McLuckey, Principles of collisional activation in analytical massspectrometry, J. Am. Soc. Mass Spectrom. 3 (6) (1992) 599-614.

[6] R. Aebersold, D.R. Goodlett, Mass spectrometry in proteomics, Chem. Rev. 101 (2001) 269-295.

[7] D.F. Hunt, J.R. Yates III, J. Shabanovitz, S. Winston, C.R. Hauer, Protein sequencing by mass spectrometry, Proc. Natl. Acad. Sci. U.S.A. 83 (1986) 6233-6237.

[8] H. Steen, M. Mann, The ABCs (and XYZs) of peptide sequencing, Nat. Rev. Mol. Cell. Biol. 5 (2004) 699-711.

[9] P. Roepstorff, J. Fohlmann, Proposal for a common nomenclature for sequence ions in mass spectra of peptides, J. Biomed. Mass Spectrom. 11 (1984) 601

[10] K. Biemann, Contributions of mass spectrometry to peptide and protein structure, Biomed. Environ. Mass Spectrom. 16 (1988) 99.

[11] M.J. Nold, C. Wesdemiotis, T. Yalcin, A.G. Harrison, Amide bond dissociation in protonated peptides. structures of the N-terminal ionic and neutral fragments, Int. J. Mass Spectrom. Ion Process. 164 (1997) 137-153.

[12] M.J. Polce, D. Ren, C. Wesdemiotis, Dissociation of the peptide bond in protonated peptides, J. Mass Spectrom. 35 (12) (2000) 1391-1398.

[13] M.M. Cordero, J.J. Houser, C. Wesdemiotis, The neutral products formed during backbone fragmentations of protonated peptides in tandem mass spectrometry, Anal. Chem. 65 (1993) 1594-1601.

[14] T. Yalcin, C. Khouw, I.G. Csizmadia, M.R. Peterson, A.G. Harrison, Why are $b$ ions stable species in peptide spectra? J. Am. Soc. Mass Spectrom. 6 (1995) 1165-1174.

[15] N.C. Polfer, J. Oomens, S. Suhai, B. Paizs, Spectroscopic, Theoretical evidence for oxazolone ring formation in collision-induced dissociation of peptides, J. Am. Chem. Soc. 127 (2005) 17154-17155.

[16] N.C. Polfer, J. Oomens, S. Suhai, B. Paizs, Infrared spectroscopy theoretical studies on gas-phase protonated Leu-Enkephalin and its fragments: direct experimental evidence for the mobile proton, J. Am. Chem. Soc. 129 (2007) 5887-5897.

[17] S.H. Yoon, J. Chamot-Rooke, B.R. Perkins, A.E. Hilderbrand, J.C. Poutsma, V.H. Wysocki, IRMPD spectroscopy shows that AGG forms an oxazolone $b_{2}{ }^{+}$ion, J. Am. Chem. Soc. 130 (2008) 17644-17645.

[18] J. Oomens, S. Young, S. Molesworth, M. Van Stipdonk, Spectroscopic evidence for an oxazolone structure of the $b_{2}$ ion from protonated tri-alanine, J. Am. Soc. Mass Spectrom. 20 (2009) 334-339.

[19] B.J. Bythell, U. Erlekam, B. Paizs, P. Maitre, Infrared spectroscopy of fragments derived from tryptic peptides, Chem. Phys. Chem. 10 (2009) 883-885.

[20] B.J. Bythell, Á. Somogyi, B. Paizs, What is the structure of $b_{2}$ ions generated from doubly protonated tryptic peptides? J. Am. Soc. Mass Spectrom. 20 (2009) 618-624.

[21] B. Paizs, S. Suhai, Fragmentation pathways of protonated peptides, Mass Spectrom. Rev. 24 (2005) 508-548.

[22] T. Yalcin, A.G. Harrison, Ion chemistry of protonated lysine derivatives, J. Mass Spectrom. 31 (1996) 1237-1243.

[23] Y.-P. Tu, A.G. Harrison, The $b_{1}$ ion derived from methionine is a stable species, Rapid Commun. Mass Spectrom. 12 (1998) 849-851.

[24] W. Yu, J.E. Vath, M.C. Huberty, S.A. Martin, Identification of the facile gasphase cleavage of the Asp-Pro and Asp-Xxx peptide bonds in matrix-assisted laser desorption time-of-flight mass spectrometry, Anal. Chem. 65 (1993) 3015-3023.

[25] J.M. Farrugia, T. Taverner, R.A.J. O'Hair, Side-chain involvement in the fragmentation reactions of protonated methyl esters of histidine and its peptides, Int. J. Mass Spectrom. 209 (2001) 99-112.

[26] J.M. Farrugia, R.A.J. O'Hair, G.A. Reid, Do all $b_{2}$ ions have oxazolone structures? Multistage mass spectrometry and ab initio studies on protonated $\mathrm{N}$-acyl amino acid methyl ester model systems, Int. J. Mass Spectrom. 210-211 (2001) 71-87. 
[27] I.P. Csonka, B. Paizs, G. Lendvay, S. Suhai, Proton mobility and main fragmentation pathways of protonated lysylglycine, Rapid Commun. Mass Spectrom. 15 (2001) 1457-1472.

[28] M. Knapp-Mohammady, A.B. Young, B. Paizs, A.G. Harrison, Fragmentation of doubly-protonated Pro-His-Xaa tripeptides: formation of $b_{2}{ }^{2+}$ ions, J. Am. Soc. Mass Spectrom. 20 (2009) 2135-2143.

[29] B. Perkins, J. Chamot-Rooke, S. Yoon, A. Gucinski, A. Somogyi, V.H. Wysocki, Evidence of diketopiperazine and oxazolone structures for $\mathrm{HA} b_{2}{ }^{+}$ion, J. Am. Chem. Soc. 131 (2009) 17528-17529.

[30] R.W. Vachet, B.M. Bishop, B.W. Erickson, G.L. Glish, Novel peptide dissociation: gas-phase intermolecular rearrangement of internal amino acid residues, J. Am. Chem. Soc. 119 (24) (1997) 5481-5488.

[31] J. Yagüe, A. Paradela, M. Ramos, S. Ogueta, A. Marina, F. Barabona, J.A. Lopez de Castro, J. Vazquez, Peptide rearrangement during ion trap fragmentation: added complexity to MS/MS spectra, Anal. Chem. 75 (2003) 1524-1535.

[32] A.G. Harrison, A.B. Young, C. Bleiholder, S. Suhai, B. Paizs, Scrambling of sequence information in collision-induced dissociation of peptides, J. Am. Chem. Soc. 128 (2006) 10364-10365.

[33] L. Mouls, J.L. Aubagnac, C.C. Enjalbal, Low energy peptide fragmentations in an ESI-Q-TOF type mass spectrometer, J. Proteome Res. 6 (2007) 1378-1391.

[34] C. Bleiholder, S. Osburn, T.D. Williams, S. Suhai, M. Van Stipdonk, A.G. Harrison, B. Paizs, Sequence-scrambling pathways of protonated peptides, J. Am. Chem. Soc. 130 (2008) 17774-17789.

[35] A.G. Harrison, Sequence scrambling through cyclization of $b_{5}$ ions, J. Am. Soc. Mass Spectrom. 19 (2008) 1776-1780.
[36] I. Riba-Garcia, K. Giles, R.H. Bateman, S.J. Gaskell, Evidence for structural variants of a- and b-type peptide fragment ions using combined ion mobility/mass spectrometry, J. Am. Soc. Mass Spectrom. 19 (2008) 609-613.

[37] U. Erlekam, B.J. Bythell, D. Scuderi, M. Van Stipdonk, B. Paizs, P. Maitre, Infrared spectroscopy of fragments of protonated peptides. Direct evidence for macrocyclic structure of $b_{5}$ ions, J. Am. Chem. Soc. 131 (2009) 11503-11508.

[38] A.G. Harrison, Cyclization of peptide $b_{9}$ ions, J. Am. Soc. Mass Spectrom. 20 (2009) 2248-2253.

[39] S. Molesworth, S. Osburn, M. Van Stipdonk, Influence of size on apparent scrambling of sequence during CID of b-type ions, J. Am. Soc. Mass Spectrom. 20 (2009) 2174-2181.

[40] A.E. Atik, T. Yalcin, A systematic study of acidic peptides for b-type sequence scrambling, J. Am. Soc. Mass Spectrom. 22 (2011) 38-48.

[41] A. Fattahi, B. Zekavat, T. Solouki, H/D exchange kinetics: experimental evidence for formation of different $b$ fragment ion conformers/isomers during the gasphase peptide sequencing, J. Am. Soc. Mass Spectrom. 21 (2010) 358-369.

[42] S. Molesworth, S. Osburn, M. Van Stipdonk, Influence of amino acid side chains on apparent selective opening of cyclic $b_{5}$ ions, J. Am. Soc. Mass Spectrom. 21 (2010) 1028-1036.

[43] X. Chen, L. Yu, J.D. Steill, J. Oomens, N.C. Polfer, Effect of peptide fragment size on the propensity of cyclization in collision-induced dissociation: oligoglycine $b_{2}-b_{8}$, J. Am. Chem. Soc. 131 (2009) 18272-18282.

[44] B.J. Bythell, M. Knapp-Mohammady, B. Paizs, A.G. Harrison, Effect of the His residue on the cyclization of $b$ ions, J. Am. Soc. Mass Spectrom. 21 (2010) 1352-1363. 